area of the protergum (Plate III, Fig. 5). The mouthparts are all larviform. The basal joint of the antennæ is larviform and chitinized; the remainder of the antennæ is membranous and typically pupiform. The eyes are typically pupiform with a membranous area surrounding t'hem, which connects the eye with the larviform cheeks. The wing pads are well developed, but the elytral pads do not bear the normal striation found in typical pupa. The base of the wing pads is surrounded by a membranous area and the pads seem to arise in the spiracular area. The specimen measures $23 \mathrm{~mm}$. in length, the dorsum of the ninth abdominal segment measures $2.996 \mathrm{~mm}$. in length, and $2.14 \mathrm{~mm}$. in width. The first thoracic tergite is $1.498 \mathrm{~mm}$. long.

This particular case of prothetely seems to be a carrying forward of larval characters into the pupal stage rather than a carrying back of pupal characters into the larval stages. Such being the case, it is possible and even probable that by the successful emergence of such a pupa some larval characters would be carried into the adult stage, and if such characters were of some material advantage to their possessors natural selection might here find variations which could lead to the production of such species with larviform adults as do exist in certain other Coleopterous genera.

\title{
TWO NEW THYSANOPTERA FROM WEST AFRICA, WITH A NOTE ON THE SYNONYMY OF THE PHLEOTHRIPIDAE.
}

\author{
By J. Douglas Hood, \\ United States Biological Survey, Washington, D. C.
}

The new species described below were sent to me in October, 1915, from Ossidinge, Kamerun, by Lieut. A. W. Jobbins-Pomeroy, of the Nigeria Regiment, West African Frontier Force. Partly in recognition of his devotion to entomology under such adverse circumstances, and partly as a mark of personal regard, I have taken great pleasure in naming one of the species in his honor. 


\section{Suborder Tubulifera Haliday. Family Phlocothripide Uzel. ${ }^{1}$}

1836. Tubulifera ("Stirps et Fam.") Haliday, Ent. Mag., Vol. III, p. 441.

1895. Phloothripidae Uzel, Monogr. Ordn. Thys., p. 223.

1896. Tubuliferidø Beach, Proc. Iowa Acad. Sci., Vol. III, p. 214.

1912. Ecacanthothripidce Bagnall, Ann. Mag. Nat. Hist., Ser. 8, Vol. X, p. 222.

1915. Eupalhithripidae Bagnall, Journ. Linn. Soc., Zool., Vol. XXXII, No. 220, p. 200.

In explanation of the above synonymy, it may be said that on the accompanying plate are given several detail drawings, which show the close similarity obtaining between Phloothrips, Acanthothrips, and Pselaphothrips, and, consequently, the relationship of all with Eupathithrips and Sedulothrips. They are discussed below under the species headings.

Acanthothrips nodicornis Reuter, Fig. 7. (Drawn from a specimen ex collection O. M. Reuter, from Helsingfors, Finland.) It will be noted that the eyes of this species differ in no essential features from those of Pselaphothrips (Fig. 2); they are as finely and closely faceted, fully as prominent, very nearly as contiguous anteriorly and show almost as great a tendency to surround the ocelli; while on the ventral surface, it may be added, they are just as well separated.

Acanthothrips albivittatus Hood, Fig. 6. The antennæ of this species are very similar to those of Pselaphothrips, in color, form, and chrtotaxy. With but few exceptions, every bristle and every sense cone finds its analogue in Pselaphothrips (Fig. 3). Furthermore, the antennæ are inserted more on the ventral than on the dorsal surface of the head; and the latter, while not crested dorsally, is nevertheless slightly elevated along the median line.

Acanthothrips magnafemoralis Hinds, Fig. 5. The third antennal segment is in this more slender than in the other species of the genus, and approaches the Pselaphothrips-Eupathithrips-Sedulothrips type very closely.

Phloothrips coriaceus Haliday, Fig. 4. (Drawn from a specimen ex collection R. S. Bagnall, from Balsall Common, Warwickshire,

\footnotetext{
I The names AEolothripidæ, Thripidæ, and Phlœothripidæ were proposed by Uzel in 1895, and should be credited to him, instead of to Haliday. The latter proposed three family namesColeoptrata, Stenoptera, and Tubulifera,- the last being employed also as a subordinal term. According to modern ideas, Haliday's names are invalid, because not formed from the oldest genus of the family by the addition of -idæ to the root.
} 
England.) Here, again, the same general type of chætotaxy prevails, the number and arrangement of sense cones and bristles being almost identical.

This disposes of all the characters used in the separation from the Phloothripidæ of the genera allied to Eupathithrips, with the exception of that of the long mouth cone. This character, however, frequently varies in closely allied species of the same genus; and in the genera grouping themselves about Liothrips, the mouth cone is sometimes as elongate as here.

These are, in detail, the reasons for the sinking of Bagnall's recently diagnosed family Eupathithripidæ as a synonym of the Phlœothripidæ. It will be seen that the twelve or thirteen differences given by him for the separation of this group are broken down in a most interesting manner by the new genus described below as Pselaphothrips, which is in nearly all respects intermediate between Eupathithrips Bagnall and Acanthothrips $\mathrm{Uzel}^{1}$; and the last genus is very closely allied indeed to Phloothrips Haliday, the type of its family. Eupathithrips and its allies, then, for the present, at least, are best considered part of a moderately large complex represented by Phloothrips, Ecacanthothrips and Sedulothrips. The last two are the extremes of two different lines of specialization; and to separate either from the parent stem with the rank of family would, I believe, be a step backward, and one away from our ideal of a true phylogenetic classification.

\section{Genus Podothrips Hood.}

1913. Podothrips Hood, Ins. Insc. Menstr., Vol. I, p. 67.

Body depressed, glabrous. Head longer than wide, much narrowed toward base, widest behind eyes, about equal in length to prothorax, evenly declivous in front; cheeks nearly smooth, without spiniferous tubercles. Ocelli placed far forward, the median one between basal segments of antennæ; posterior ocelli widely separated. Antennæ eight-segmented, the last two segments not compactly united. Mouth cone blunt, much shorter than its width at base. Prothorax about as long as head, about twice as wide at base as at apex, lobed behind, with median dorsal thickening, lateral outline concave, only the two pairs of bristles at posterior angles well developed. Legs of moderate length, stout; fore femur nearly as long and broad as head; fore tibia with a stout tooth at tip in both sexes; fore tarsus armed with a

\footnotetext{
1 Karny's Acanthothrips grandis described from Argentina (Zoöl. Ann., Vol. IV, p. 324, 1912), is almost certainly a Eupathithrips, though a more extensive description or an examination of the type specimen will be necessary before this point can be determined. There is nothing in the description to exclude the speeies from Eupathithrips silvestrii (Buffa)
} 
long hooked tooth. Wings slender, narrowed at middle; fringe sparse and weak, on fore wing not double along posterior margin near apex.

Type: Podothrips semiflavus Hood.

The new African species described below has made necessary two or three slight changes in the original description of the genus. The two known species are strictly congeneric, though differing abruptly in color and certain details of structure.

\section{Key to Species.}

a. Yellow, with head, sides of metathorax, and last three abdominal segments abruptly dark brown; cheeks rounded behind eyes, not toothed

Podothrips semiflavus Hood.

aa. Dark blackish brown, with antennal segments $3-7$, the fore tibiæ, all tarsi, and first abdominal segment yellow; cheeks with a distinct, lateral, acute tooth behind eyes.................... Podothrips denticeps Hood.

Podothrips denticeps sp. nov.

Female: Length about $1.8 \mathrm{~mm}$. Surface shining. Color dark blackish brown, with antennal segments 3-7, fore tibiæ, all tarsi, and first abdominal segment, pale lemon yellow; wings pale yellowish, darker toward base.

Head 1.35 times as long as wide, with a distinct, lateral, acute, and more or less forwardly directed tooth just behind eye, thence arcuately converging to near base, where there is a slight neck-like constriction; vertex rounded and evenly declivous; dorsal surface without sculpture; cheeks very slightly roughened, sparsely and briefly spinose; postocular bristles slightly knobbed, two-thirds as long as eyes, situated close to lateral margins of head. Eyes one-third as long as head and threefourths as wide as their interval, not protruding, ventral extent very slightly less than dorsal. Ocelli anterior in position, the posterior pair near the anterior angle of eyes, the median ocellus between basal segments of antennæ. Antennæ nearly 1.5 times as long as head, moderately slender; segment 1 slightly broader at base than ventral length; 2 narrower than 1 , nearly twice as long as wide; 3 elongate-oval, pedicellate, with a slight notch on inner surface at basal third, nearly twice as long as wide; 4-6 elongate-oval, subequal in length and successively decreasing in width, briefly pedicellate, 4 slightly broader than 2 and $3 ; 7$ slender, very slightly longer than 6 , about 2.4 times as long as wide; 8 fusiform-truncate, very slender and nearly 0.9 as long as 7, about four times as long as greatest width; sense cones and bristles unusually short and weak; segments 1 , 2, and 8 nearly concolorous with head, 2 yellow in outer apical half; intermediate segments clear lemon yellow, except 7, which is lightly washed with brown.

Prothorax about five-sixths as long as head and (inclusive of coxæ) twice as wide at base as at apex and 0.7 as long as wide; lateral outline concave; surface smooth; median dorsal line distinctly chitinized; all usual bristles present, the anterior marginal pair visible only under highest magnifications; the anterior angular and midlateral pairs only slightly larger; the two pairs near the posterior angles and the coxal pair knobbed, nearly as long as postoculars. Pterothorax about as wide as 
base of prothorax, sides nearly straight and parallel. Legs moderately stout; fore femur nearly as long as head and about twice as long as greatest width; fore tibia stout, scarcely as long as width of femur, with a stout, prominent tooth on inner side of apex, just basal to which is a setose tubercle; fore tarsus with a long, strong, hooked tooth about two-thirds its length, the inner surface of tooth with a setose tubercle at apical two-fifths. Wings long, slender, weak, slightly suffused with yellowish (particularly toward base), without double subapical fringe.

Abdomen slender, slightly wider than pterothorax. Tube nearly 0.6 as long as head, basal fourth slightly swollen, nearly 2.5 times as wide as apex; terminal bristles brown, about 1.5 times as long as tube; all other abdominal bristles pale, in great part knobbed.

Measurements of holotype (female): Length $1.81 \mathrm{~mm}$; head, length $0.252 \mathrm{~mm}$., width $0.186 \mathrm{~mm}$.; prothorax, length $0.205 \mathrm{~mm}$., width (inclusive of coxæ) $0.300 \mathrm{~mm}$;; pterothorax, width $0.288 \mathrm{~mm}$.; abdomen, width $6.307 \mathrm{~mm}$.; tube, length $0.144 \mathrm{~mm}$., width at base $0.074 \mathrm{~mm}$., at apex $0.030 \mathrm{~mm}$.

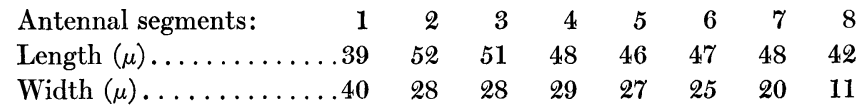

Total length, $0.373 \mathrm{~mm}$.

Described from a unique female collected by Lieut. A. W. Jobbins-Pomeroy, on grass, near Ossidinge, Kamerun, in October, 1915 .

\section{Genus Pselaphothrips nov.}

( $\psi \eta \lambda \alpha \phi \sigma \omega$, to feel $^{1}$; $\Theta \rho \iota \psi$, a wood worm.)

Body not depressed. Head much less than twice as long as wide, and more than twice as long as prothorax, compressed and subcarinate above; cheeks nearly parallel, not at all swollen toward base, and with a few small spiniferous tubercles; vertex sulcate and nearly overhanging in front of anterior ocellus. Eyes moderate in size, finely and closely faceted, scarcely prominent or protruding, well separated anteriorly, slightly reniform, exhibiting little tendency to surround the ocelli. Ocelli anterior, not set on an elevation, the median one directed nearly forward, the posterior pair approximate. Antennæ eight-segmented, nearly twice as long as head, scarcely "set on ventral surface of head," moderately slender, intermediate segments stout (that is, for the group; in the genotype scarcely three times as long as wide), clavate, distally abruptly narrowed; sense cones long and slender. Mouth cone very long and slender, attaining base of mesosternum. Prothorax broadly arcuate (scarcely emarginate) in front, its median dorsal length more than one-third the width across coxæ. Legs moderately slender; fore femora not swollen, with an acute tooth on inner surface near apex; fore tarsi armed. Wings slender, of equal width throughout; fore pair with a subbasal dark band and many accessory hairs on posterior margin.

Type: Pselaphothrips pomeroyi sp. nov.

1 In reference to the apparently very sensitive antennæ,- -although the function of the conidia is presumably olfactory instead of tactile. 
This genus is closely allied to Acanthothrips, Eupathithrips, and Sedulothrips, but differs from the last two in a number of characters which Bagnall considers of family importance. From Acanthothrips it may be separated by the long mouth cone and the compressed and subcarinate dorsum of the head. It is the only member of the Eupathithrips group occurring outside the Neotropical region.

\section{Pselaphothrips pomeroyi sp. nov.}

Female: Length about $3 \mathrm{~mm}$. Color dark blackish brown, with purple hypodermal pigmentation in head, thorax, and abdomen; antennæ and legs concolorous with body; tube paler in apical half.

Head 1.44 times as long as wide, compressed and subcarinate above; cheeks nearly parallel, not at all swollen toward base, anteriorly roundly converging to eyes, set with a few small spiniferous tubercles; vertex sulcate and nearly overhanging in front of anterior ocellus; postocular bristles short, scarcely one-fourth as long as eyes, dilated at tip. Eyes very finely and closely faceted, not at all protruding, nearly 0.4 as long as head, well separated anteriorly, slightly reniform, showing little tendency to surround the ocelli. Ocelli anterior, not set on an elevation, the median one directed nearly forward and distinctly removed from the approximate posterior pair. Antennæ about 1.9 times as long as head, moderately slender, uniform dark blackish brown in color; segments 3-6 clavate, abruptly narrowed apically, urn-or vase-shaped, 3-5 about 2.7 and 6 about 2.4, times as long as wide; 7 fusiform-truncate, closely united to 8 , which is conical; 4 slightly longer than 3 ; sense cones long, slender, broad at base, those on segment 3 more than half the length of segment; formula: $3,1-2 ; 4,2-2^{+1} ; 5,1-1^{+1} ; 6,1-1^{+1} ; 7$ with one on dorsum near apex. Mouth cone and palpi very long, the former acute and attaining metasternum.

Prothorax broadly arcuate (scarcely emarginate) in front, its median dorsal length about 0.43 of that of head and 0.37 of the width across coxæ; pronotum nearly smooth, with faint anastomozing lines in posterior third and at sides, and with rather conspicuous short pubescence; median line slightly chitinized; all usual bristles present, and with an additional accessory pair arising mediad and cephalad to the base of the outer posterior pair, all short, dilated at tip, equal to or longer than postoculars, the outer pair at posterior angles longest. Pterothorax about equal in width to prothorax, sides nearly straight, slightly converging posteriorly. Wings long, closely fringed, fore pair with about 35 accessory hairs on posterior margin, and of equal width throughout; fore wings with the scale dark brown and in costal half reticulated similarly to the mesonotum; a dark brown, stippled, granulate, cross band occupies the second sixth, and a lighter brown cloud the apical two-fifths of fore wing, these connected and at least partially traversed by the dark median vein, and in addition connected along both margins of wing by a brown line; third basal spine of fore wing, dark brown, long, slender, and slightly knobbed at tip, set in a small, isolated, stippled, brown spot; first and second basal spines pale, short, stout, and rather strongly dilated at tip, surrounded by an obscurely darkened and sparsely stippled area. Legs moderately slender; fore femora not swollen, with an acute 
tooth on inner surface near apex, and with numerous minute spines, stouter on inner surface; fore tibiæ with slenderer spines; fore tarsi with a blunt tooth on inner surface.

Abdomen slender, about equal in width to the pterothorax. Tube about threefourths as long as head and a little less than half as wide at apex as at base, paler in apical half. Marginal abdominal bristles (excepting those on segment 9, which are pointed and about equal in length to tube) moderately short, blunt, yellowish; terminal bristles slightly longer than tube, brown, pointed.

Measurements of holotype: Length $2.93 \mathrm{~mm}$; head, length $0.468 \mathrm{~mm}$., width $0.324 \mathrm{~mm}$.; prothorax, length (along median dorsal line) $0.204 \mathrm{~mm}$., width (inclusive of coxæ) $0.558 \mathrm{~mm}$.; pterothorax, width $0.552 \mathrm{~mm}$.; abdomen, width $0.552 \mathrm{~mm}$; tube, length $0.348 \mathrm{~mm}$., width at base $0.122 \mathrm{~mm}$., at apex, $0.066 \mathrm{~mm}$.

$\begin{array}{lrrrrrrrr}\text { Antennal segments: } & 1 & 2 & 3 & 4 & 5 & 6 & 7 & 8 \\ \text { Length }(\mu) & 78 & 87 & 165 & 174 & 154 & 94 & 78 & 47 \\ \text { Width }(\mu) & 49 & 41 & 60 & 63 & 57 & 39 & 33 & 18\end{array}$

Total length, $0.877 \mathrm{~mm}$.

Described from one female taken in flight, by Lieut. A. W. Jobbins-Pomeroy, at Ossidinge, Kamerun, in October, 1915.

\title{
EXPLANATION OF PLATE IV.
}

(Minute pubescence not shown.)

Fig. 1. Podothrips denticeps sp. nov., head and prothorax, female, holotype.

Fig. 2. Pselaphothrips pomeroyi gen. et sp. nov., head and prothorax, female, holotype.

Fig. 3. Pselaphothrips pomeroyi, segments 3 and 4 of right antenna, female, holotype.

Fig. 4. Phlcothrips coriaceus Haliday, segments 3 and 4 of right antenna, female.

Fig. 5. Acanthothrips albivittatus Hood, segment 3 of right antenna, female.

Fig. 6. Acanthothrips magnafemoralis Hinds, segment 3 of right antenna, female.

Fig. 7. Acanthothrips nodicornis Reuter, head, female.

\section{A PRELIMINARY LIST OF THE ODONATA OF CONCORD,} MASS.

\author{
By R. Heber Howe, Jr., \\ Concord, Mass.
}

Two years ago I interested one of my students in making a collection of the local dragon flies of Concord for the Thoreau Museum of Natural History of the Middlesex School. This stu- 

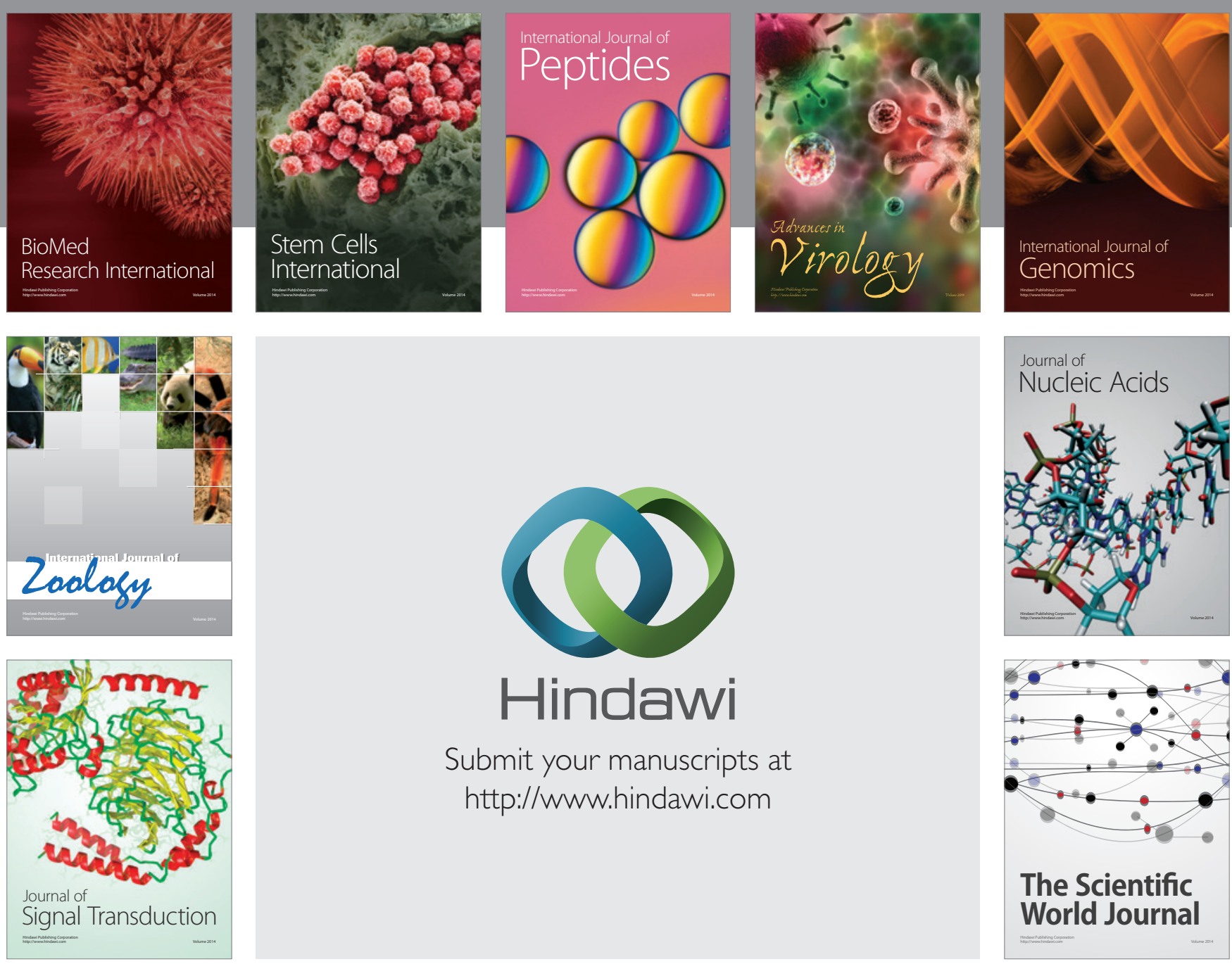

Submit your manuscripts at

http://www.hindawi.com
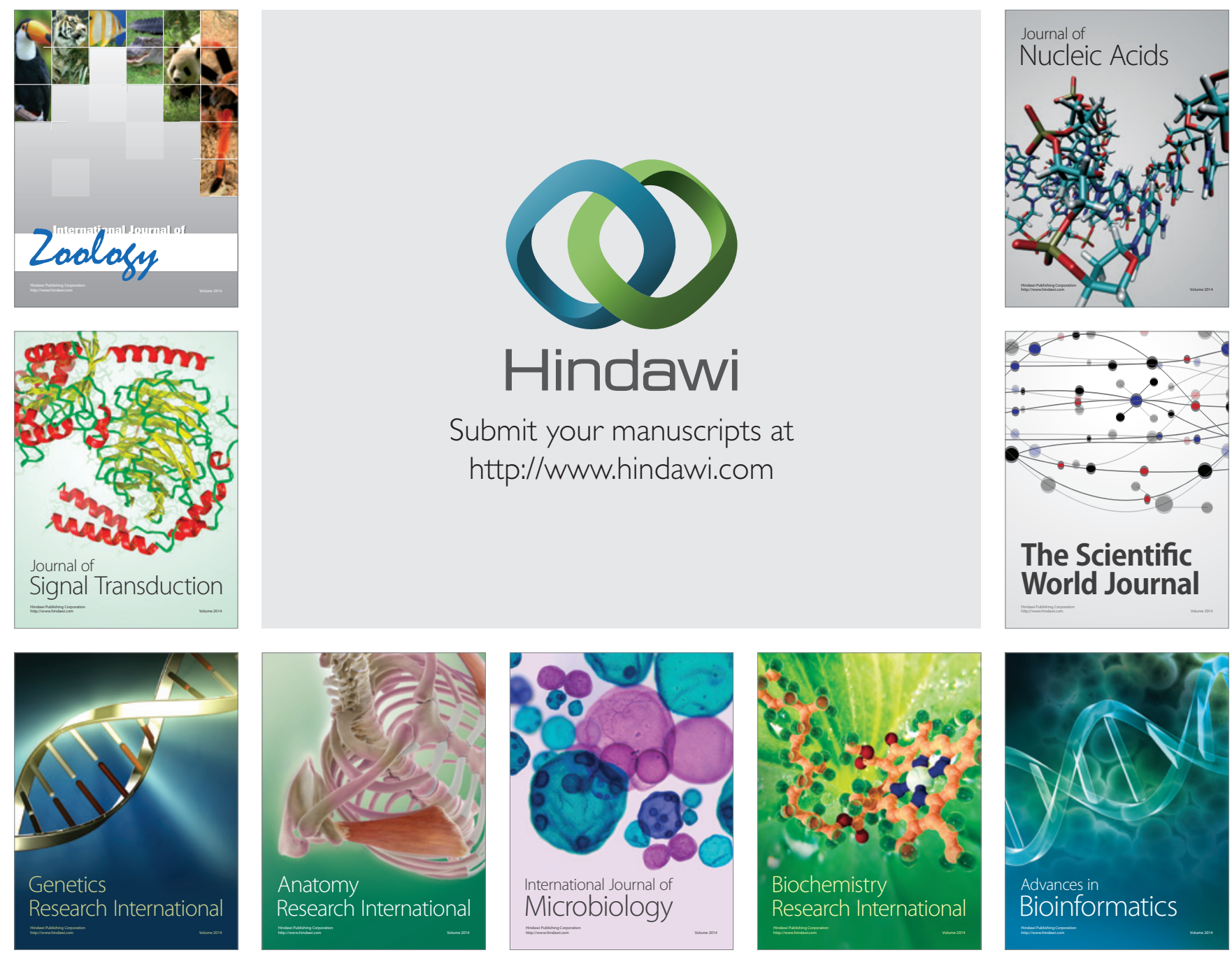

The Scientific World Journal
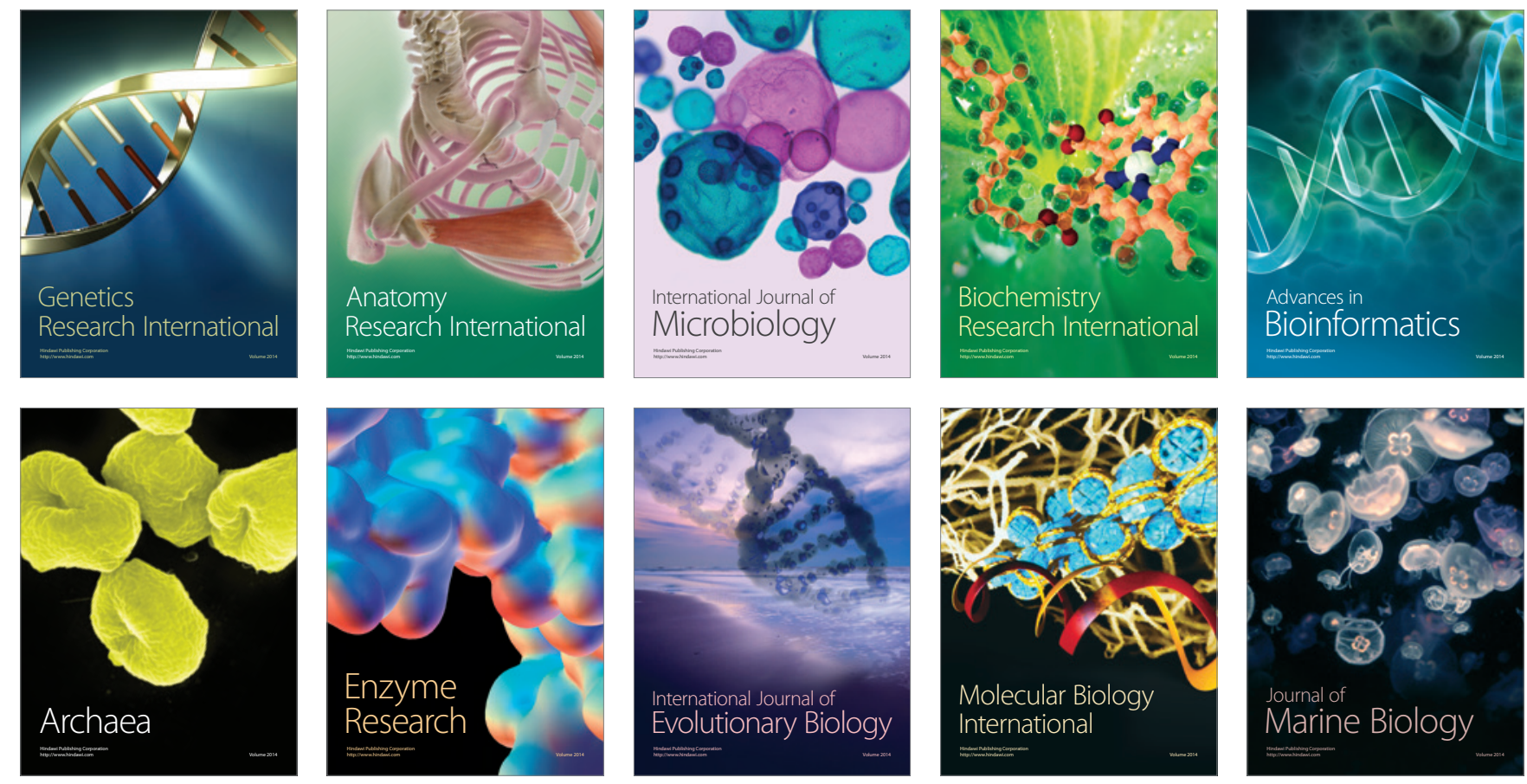